University of Michigan Law School

University of Michigan Law School Scholarship Repository

1922

\title{
Documents and Their Scientific Examination
}

\author{
Victor H. Lane \\ University of Michigan Law School
}

Available at: https://repository.law.umich.edu/reviews/144

Follow this and additional works at: https://repository.law.umich.edu/reviews

Part of the Civil Procedure Commons, Criminal Procedure Commons, Evidence Commons, and the Legal Writing and Research Commons

\section{Recommended Citation}

Lane, Victor H. Review of Documents and Their Scientific Examination, by C. A. Mitchell. Am. L. Rev.56 (1922): 797-8.

This Book Review is brought to you for free and open access by the Faculty Scholarship at University of Michigan Law School Scholarship Repository. It has been accepted for inclusion in Reviews by an authorized administrator of University of Michigan Law School Scholarship Repository. For more information, please contact mlaw.repository@umich.edu. 
DATE DOWNLOADED: Wed Aug 19 10:35:15 2020

SOURCE: Content Downloaded from HeinOnline

Citations:

Bluebook 21st ed.

56 AM. L. REV. 794 (1922).

ALWD 6th ed.

56 AM. L. REV. 794 (1922).

APA 7th ed.

(1922). American Law Review, 56(5), 794-800.

Chicago 7th ed.

"," American Law Review 56, no. 5 (September-October 1922): 794-800

OSCOLA 4th ed.

" (1922) 56 AM L REV 794

Provided by:

University of Michigan Law Library

-- Your use of this HeinOnline PDF indicates your acceptance of HeinOnline's Terms and Conditions of the license agreement available at https://heinonline.org/HOL/License

-- The search text of this PDF is generated from uncorrected OCR text. 
is set forth in sufficient detail to develop the author's thesis. Long intricate discussions of constitutional questions are carefully avoided, particularly those which do not bear directly upon the idea sought to be developed, namely, that the American Constitution is a vital force, which has, through the exercise by the courts of the right to construe it, been preserved in all its vitality, and which it is as necessary to preserve now by the same means as it was at any time in the past.

The work is not intended as a complete treatise upon the Constitution, but designed to give in as simple a manner as possible a ganeral view of the principles underlying our system of government. It is a fine contribution to the movement inaugurated by the American Bar Association at its late meeting in San Francisco, to further American ideals of citizenship and to arouse public sentiment in favor of support for the Constitution.

The publishers are The Encyclopedia Press, New York.

The Law and Custom of the Constitution. By Sir William R. Anson. Volume One. Fifth Edition by Maurice L. Gwyer. 1922.

The purpose of the author originally was to state the law relating to existing institutions, with so much history as is necessary to explain how they have come to be what they are. The first edition appeared in 1886 and the author dealt solely with Parliament.

Since the last edition there have been many changes in the statute law of Parliament of which it was necessary to treat. The recasting and extension of the franchise by the Representation of the People Act, 1918, the Creation of the Parliament of Northern Ireland, the disappearance of the representatives of Southern Ireland from the House of Commons, the presence of women in Parliament, and the Irish agreement of December 6, 1921, are the most notable recent changes.

The work will be complete in three volumes. This volume deals exclusively with Parliament.

The student of the English Constitution will find the work carefully prepared and complete.

The Clarendon Press, Oxford, are the publishers.

Documents and their Scientific Examination. By C. Ainsworth Mitchell. 1922.

This little work is based upon personal experience extending over many years and includes the results of a great variety of investigations on such subjects as the composition and behavior of inks, pencil pigments, sealing wax, and other writing materials in connection with their use upon documents.

The question of the materials upon which the writing, typing or printing appears, of handwriting, of finger prints, photography and microscopical examination have also been dealt with.

A study such as this is of material importance in presenting expert evidence in civil and criminal cases, in the investigation of anonymous 
letters and the like. Special reference is made to the chemistry involved in cases of suspected forgery, etc. Over 50 illustrations are included. This scientific little book aside from its valuable practical usefulness makes very interesting study.

The publishers are Charles Griffin and Company, Ltd., London.

Legislative Procedure. By Robert Luce. 1922.

For many years Mr. Luce has been at work on a book that would cover in detail the whole subject of law-making and representative government in the United States. This book is now finished and will be brought out in four volumes, Legislative Procedure, Legislative Assemblies, Legislative Principles, and Legislative Problems, each entirely complete in itself.

This, the first of these four volumes, is a thoroughly comprehensive treatise, in which both theory and practice of legislative procedure are exhaustively discussed in a way that illuminates the whole aspect of representative government.

Mr. Luce has served in the Massachusetts Legislature and in Congress, as lieutenant-governor of Massachuestts, and as chairman of the Conmittee of Rules and Procedure of the Massachusetts Constitutional Convention of 1917-19. His book is the result of a unique combination of original thought, long research, and years of practical experience.

Houghton Mifflin Company, Boston and New York, are the publishers.

Trade-Mark Laws of THE WorLd. Compiled and edited by John $\mathbf{H}$. Ruege and W. B. Graham. 1922.

This work, the first publication in the English language of the trademark laws of the world in extenso, is intended to meet an existing need evidenced by a constant demand on the part of those most interested in the subject of trade-marks and their protection.

The editors have taken great care to obtain the laws from trustworthy sources, and to provide reliable and accurate translations. Access to the extensive library of Mr. William Wallace White of New York has made the compilation possible.

This great compilation of the trade-mark laws of some one hundred forty-five countries will be welcomed by those whose business requires a knowledge of such laws and the editor's and the publishers, Trade-Mark Law Publishing Company, New York, are to be commended upon the publication of the work.

The Control of American Foreign Reinations. By Quincy Wright. 1922.

The author is professor of international law in the University of Minnesota and winner of the Henry M. Phillips Prize offered by the 